\title{
Governance Without Democracy? Analysing the Role of Parliaments in European Economic Governance after the Crisis: Introduction to the Special Issue
}

\author{
Aleksandra Maatsch ${ }^{1, *}$ and Ian Cooper $^{2}$ \\ ${ }^{1}$ Department of Political Science, University of Cologne, Cologne, Germany; \\ ${ }^{2}$ Robert Schuman Centre for Advanced Studies, European University Institute, Fiesole, Italy \\ * Correspondence: maatsch@wiso.uni-koeln.de
}

\section{Introduction}

The recent European financial crisis has been an earthquake-like experience not only economically, but also for its impact on the democratic institutions of the European Union (EU) and its Member States. Many scholars have observed that representative democracy in EU Member States has been eroded during that period (Mair, 2011; Rose, 2014; Rittberger and Winzen, 2015; Maatsch, 2016). In particular, the financial crisis constituted a period when political deliberation often gave way to technocratic decision-making. Indeed, the most basic powers of national parliaments-their power to control the domestic budgetary process and to represent their constituents' interests during that process-have been undermined (Mair, 2011; Rose, 2014).

The reform of European economic governance took place under extreme time pressure, which opened a door to practices that allowed governments to constrain national parliaments' scrutiny and legislative powers. The ability to raise taxes and set independent budgets is a key aspect of national sovereignty and national parliaments have traditionally enjoyed significant powers in this regard. The establishment of Economic and Monetary Union imposed some constraints on states' ability to manage their own economic and budgetary affairs in theory, but in practice such constraints were typically seen only in the breach. By contrast, the EU's responses to the global economic crisis and then in particular to the Eurozone crisis have led to far more serious limitations on the powers of national parliaments, raising profound questions about democracy, legitimacy and accountability. In its attempts to resolve the Eurozone crisis, the EU has enacted a 
series of measures designed to tighten fiscal governance and national budgeting rules across EU Member States in order to stabilise the Euro and allay a seemingly existential threat to the Union.

In particular, in many states the executive decided to accelerate the legislative process by constraining parliamentary control. Governments, exposed to international pressure, frequently prioritised the interests of financial markets over those of their own voters (Mair, 2011; Rose, 2014). In states where these practices were particularly prevalent, citizens' levels of trust in national representative institutions radically decreased. ${ }^{1}$ During this period, national budgetary matters and public policies were also heavily influenced by institutions that are not directly accountable to national parliaments, such as the European Commission and the International Monetary Fund. Against this background, many scholars expressed their deep concern with the future of representative democracy in Europe (Crouch, 2011; Scharpf, 2012; Streeck, 2014). If national parliaments no longer serve as the main arenas for national economic debate and decision-making, how can Member State governments and the supranational EU institutions be held publicly accountable for their actions in this policy area?

To explore these concerns, this Special Issue analyses the role of national parliaments in European economic governance after the financial crisis and asks the following questions: how have national parliaments responded and adapted to the reforms of European economic governance necessitated by the Eurozone crisis? What impact does their response have on the democratic legitimacy and accountability of EU economic governance? These questions stem from the two fundamental theoretical concerns, one explanatory and the other normative, which inform this Special Issue. The first concern is to explain how national parliaments contribute to the functioning of European economic governance; the second is to evaluate these changes systematically to assess their effect on the democratic legitimacy of the EU in the field of economic governance.

In analytical terms, the goal of this Special Issue is to enhance our understanding on how the new, post-crisis, system of economic surveillance affects the input and the output legitimacy of European economic governance (Schmidt, 2006; Scharpf, 2012). For this purpose, we define input legitimacy as the accountability structure between domestic or European decision makers and national representative institutions, i.e. parliaments; and we define output legitimacy as the effectiveness of policy outcomes, i.e. the consent and recognition of implemented policies by domestic actors.

\footnotetext{
${ }^{1}$ According to the Eurobarometer surveys.
} 


\section{Challenges to democratic control: bailout funds and the reform of the Stability and Growth Pact}

Parliamentary control is decisive for the legitimacy of the budgetary process. National parliamentary parties, directly elected by citizens, aggregate and voice the interests of their constituents in the parliament. In modern democracies national parliaments constitute a forum where national budgets are debated and formally approved. Although governments take the lead in the budgetary process by preparing budgetary drafts, national parliaments are not only authorised to debate and to approve the budget, but also-in most cases - to propose amendments (Ruiz Almendral, 2015). Plenary debates concerning the budgetary process allow parliamentary parties of both the government and the opposition to critically evaluate the debated budget from the perspective of their constituents' economic interests. Not surprisingly, the conflict over redistribution has been persistently very important in domestic politics. If representative institutions fail to control and influence critical decisions regarding public expenditures, the constitutive criterion for representative democracy cannot be met (Merkel, 2014).

With the financial crisis, national and European decision makers were confronted with two major challenges. They had to, first, establish mechanisms providing immediate financial assistance to states facing serious liquidity problems and, second, reform the Stability and Growth Pact (SGP) in order to prevent a similar financial crisis in the future. Both the establishment of bailout funds and the reform of the SGP affected national parliaments' powers to influence the content of public policies and to hold the decision makers accountable.

\subsection{Bailout funds}

Article 125(1) of the Treaty on the Functioning of the European Union (TFEU) clearly prohibited financial assistance (bailouts) to signatories of the Treaty. Nonetheless, governments decided that action was needed to prevent the default of Greece and to diminish the risk of contagion in the whole Eurozone. Under extreme time pressure, decision makers decided to bypass the existing EU law and provide financial assistance through alternative instruments. A Treaty reform was postponed given the pressing need to ensure liquidity of Southern European states and Ireland. The temporary bailout fund, the European Financial Stability Facility (EFSF), ${ }^{2}$ was therefore established outside the existing EU law as a private company owned by governments of the Eurozone Member States. The permanent bailout fund, the European Stability Mechanism, replaced the EFSF after the

\footnotetext{
${ }^{2}$ The EFSF is a fund in which capital guarantees are provided by Member States of the Eurozone (440 billion euros). The EFSM (European Financial Stability Mechanism), established by Directive 407/ 2010, used the budget of the EU as collateral (60 billion euros).
} 
amendment of Article 136(3) of the TFEU stipulating that 'The member states whose currency is the euro may establish a stability mechanism to be activated if indispensable to safeguard the stability of the euro as a whole. The granting of any required financial assistance under the mechanism will be made subject to strict conditionality'. The permanent bailout fund was also established outside the EU legal framework, namely as an intergovernmental organisation.

Although these measures were deemed necessary for the very survival of Economic and Monetary Union and to secure the future of the Union, troubling questions remain as to their impact on the democratic legitimacy of economic governance in the EU and its Member States. In particular, the establishment of the temporary and the permanent bailout fund was dominated by national governments while the role of national parliaments, and the European Parliament (EP) in particular, was very limited in that process. As the establishment of the bailout funds took place outside the EU legal framework, the ordinary legislative procedure was not applied and the EP could not be involved as a co-legislator in the process.

While the bailout funds had to be unanimously approved in all Member States of the Eurozone, governments opted for various measures limiting the likelihood of a disruption of the approval process (Rittberger and Winzen, 2015). These measures constrained national parliaments' powers: for instance, in Southern European (bailout) states, governments frequently opted for fast-track procedures limiting or eliminating parliamentary readings or voting (Maatsch, 2017). The other common measure employed, merger legislation, combined two or more pieces of legislation that have to be approved or rejected by a parliament with only one vote. These measures prevented national parliaments from exercising full control of the legislative process.

Whereas fast-track procedures and merger legislation were frequent in Southern European parliaments, they were practically entirely absent from Northern European parliaments. As a consequence, the democratic control of the reform process was weaker in states that were economically and institutionally most affected by the financial crisis. Interestingly, while national supreme or constitutional courts in Northern Europe actively objected to the disempowerment of national parliaments in their states, Southern European courts acted as allies of the executive and did not find the excessive use of fast-track procedures or merger legislation to be unconstitutional (Maatsch, 2017).

The acquisition of loans ('bailouts') became dependent on parliamentary approval of Memoranda of Understanding (MOUs) proposed by the so-called 'Troika', made up of three institutions that are not directly accountable to national parliaments (the Commission, the European Central Bank and the International Monetary Fund). The MOUs stipulate various budgetary reforms (usually reductions in expenditure) that bailout states are required to implement. Furthermore, acquisition of bailout loans also became conditioned on successful 
ratification of the Treaty on Stability, Coordination and Governance in the Economic and Monetary Union (TSCG, also known as the 'Fiscal Compact'). National parliaments in bailout states thereby agreed to give up some of their sovereign powers in national budgetary politics.

\subsection{Reform of the SGP}

The new policy tools stipulated in the TSCG, the six-pack ${ }^{3}$ and more rigorous two-pack ${ }^{4}$ as well as the European Semester had an impact on both parliamentary budgetary procedures and on the national budgets themselves. First, the European Semester, ${ }^{5}$ which applies to all 28 Member States, and the two-pack, applicable only to Eurozone members, introduced a yearly cycle of economic policy coordination in which the EU Members States are expected to work with the European Commission in drafting their national budgets. Indeed, the Commission acquired the right not only to express its opinion but to ask for budgetary revisions. Secondly, the TSCG, an agreement among 25 EU Member States which came into effect in 2013, stipulated that the budget deficit in Eurozone states shall not exceed 3\% and the structural deficit 1\% of GDP, whereas the debt to GDP ratio should not exceed $60 \%$. However, the major innovation of the whole reform was the widening of surveillance beyond budgetary matters to also cover macroeconomic imbalances and changes in competitiveness. In addition, the reform has revised the system of sanctions that can be imposed on states breaching the rules.

The literature identifies three major innovations introduced with the reform of European economic governance (Thygesen, 2013). First, the mechanism of the

\footnotetext{
${ }^{3}$ The six-pack is composed of: Regulation 1175/2011 amending Regulation 1466/97: On the strengthening of the surveillance of budgetary positions and the surveillance and coordination of economic policies, Regulation 1177/2011 amending Regulation 1467/97: On speeding up and clarifying the implementation of the excessive deficit procedure, Regulation 1173/2011: On the effective enforcement of budgetary surveillance in the euro area, Directive 2011/85/EU: On requirements for budgetary frameworks of the Member States, Regulation 1176/2011: On the prevention and correction of macroeconomic imbalances, Regulation 1174/2011: On enforcement action to correct excessive macroeconomic imbalances in the euro area.

${ }^{4}$ The two-pack is composed of: Regulation 473/2013: On common provisions for monitoring and assessing draft budgetary plans and ensuring the correction of excessive deficit of the Member States in the euro area and Regulation 472/2013: On the strengthening of economic and budgetary surveillance of Member States in the euro area experiencing or threatened with serious difficulties with respect to their financial stability.

${ }^{5}$ The legal basis of the European Semester is provided in the six-pack, the two-pack and Article 121 TFEU on the Broad Economic Policy Guidelines and Article 148 TFEU on the Employment Guidelines.
} 
European Semester created an institutional framework allowing EU institutions to examine national budgets earlier and in a more systematic manner than before. The thorough examination and approval of national budgetary proposals takes place before national parliaments approve their budgets. It is true that national parliaments remain the major actors whose consent is necessary in order to approve a national budget. Yet the EU institutions (the Commission, the Council of Ministers and the European Council) acquired substantial influence not only to examine national budgets but also to suggest far-reaching policy recommendations and to impose sanctions on national governments in cases of noncompliance.

Secondly, the reform introduced a more forceful system for reducing deficits and, thirdly, it altered the procedures for the adoption of recommendations by the European Council. In the same vein, the possible sanctions imposed on noncomplying governments also became more restrictive. In particular, the reform introduced Reverse Qualified Majority Voting (RQMV) according to which a recommendation issued by the Commission should be adopted unless the Council decides by qualified majority to reject that recommendation. Theoretically, RQMV generates an impression that sanctions are quasi-automatic so that the new system generates stronger pressure on national governments. However, as no sanctions have been imposed so far on states that breach the rules, it may be argued that the new voting procedure is more about deterrence.

As many authors have observed, this reform has contributed to an accountability gap (Cygan and Lord in this volume). While the Commission and the Council have acquired stronger powers to influence national budgets, parliamentary scrutiny has not been correspondingly strengthened. In particular, in budgetary matters, national parliaments can only hold their own governments accountable. Neither national parliaments, nor the EP, can effectively control the process of formation of country-specific recommendations at the EU level, which are proposed by the Commission but debated and adopted by the Council. That generates a major challenge, for, as Christopher Lord observes in this special issue (2017: 7) ensuring parliamentary accountability is difficult when 'responsibility for outcomes is not directly attributable to only one institution but arises instead from interactions between them'.

A new avenue that national parliaments could use to increase their influence in the wake of the financial crisis would be to take action collectively at the EU level. National parliaments as a group could, with or without the collaboration of the $\mathrm{EP}$, work together to discuss and oversee the new EU economic regime. However, their efforts in this regard have as yet had little impact. The InterParliamentary Conference on Stability, Economic Coordination and Growth (SECG Conference), which is an outgrowth of Article 13 TSCG, has been largely 
ineffective. It has not given national parliaments an opportunity to directly scrutinise the EU executive and hold it accountable for its conduct in the European Semester (Cooper, 2016).

Moreover, the overall institutional position of the EP has been disadvantaged by the financial crisis, in that many of the post-crisis governance measures have been enacted outside the traditional Community method, and thus are only partly within the realm of the oversight of the EP (Fasone, 2014). Yet instead of collaborating with national parliaments in the joint oversight of European economic governance, the EP has pushed for institutional or treaty changes that would expand its own powers of scrutiny in this area.

\section{The content of this special issue}

All four major articles in this Special Issue examine the democratic legitimacy of the post-crisis EU with a particular focus on national parliaments. Each of the papers approaches the problem in a different way, but they are complementary. Adam Cygan offers a broad assessment of European economic governance in the context of the long-standing legal and constitutional traditions and institutional architecture of the EU: he is concerned not only with the erosion of the EU's democratic legitimacy as it concerns national parliaments, but also, more generally, the effect on the institutional balance between executive and legislative authorities at all levels, as well as on the principles of the equality of, and solidarity between, Member States. Ian Cooper also takes a broad view, assessing the democratic legitimacy of European economic governance as it affects non-Eurozone Member States; he is concerned with identifying the outer edges of the regime in order to determine which states should be represented within a parliamentary body tasked with overseeing it. Christopher Lord's perspective is more focused, in that he assesses the democratic legitimacy of one particular set of policies and procedures, the European Semester; from first principles, he builds an argument for how to define significant and substantive parliamentary involvement in this process. Aleksandra Maatsch is also focused on the democratic legitimacy of the European Semester, but from the perspective of parliamentary parties; she investigates the conditions under which EU policy guidance will be contested in national parliaments.

The article by Adam Cygan offers a broad critique of European economic governance not only for its effect on democratic legitimacy-in particular, the powers of national parliaments-but also on the long-standing constitutional traditions of, and economic fairness within, the EU. He identifies some of the contradictions in the Commission's 2012 Blueprint for a Deep and Genuine Economic and Monetary Union, which failed to account for the programme's deleterious effects on institutional balance and overall level of parliamentary control 
in the EU's multilevel governance system. This judgement is borne out by the empowerment of EU-level executive actors in a way that is not counterbalanced by increased powers for the EP, the asymmetry in the response of national parliaments - with debtor state parliaments comparatively disadvantaged - and the inadequacy of any kind of collective response through the means of interparliamentary cooperation. Cygan also shows how the bedrock constitutional principles of the integrity of the single market and solidarity between Member States were upheld by the European Court of Justice in the course of rejecting a legal challenge to the establishment of the European Stability Mechanism. Even within the evolving character of the European Semester, characterized by the use of 'soft' governance tools and increased concern for socioeconomic challenges alongside budgetary discipline, national parliaments continue to struggle to exercise influence over the process.

Christopher Lord analyses the democratic legitimacy of the European Semester, understood as dependent on how it helps Member State democracies to meet their obligations to their own publics, including the management of externalities between them. Given the peculiar character of the European Semester, he sets out to define exactly how parliaments can contribute to its legitimacy, with a particular focus on the content of parliamentary involvement, its distribution among parliaments at different levels of authority, the degree of interparliamentary coordination, and its degree of uniformity. He concludes that parliaments must actively scrutinise the process from an early stage to ensure their input and avoid faits accomplis. While the involvement of national parliaments is most important, the EP with its pan-European mandate has an indispensable oversight role with respect to EU executive actors such as the ECB. Interparliamentary cooperation can help parliaments at all levels to overcome asymmetries of information and to identify positive-sum elements of the semester. Finally, perhaps some minimum standard of national parliamentary involvement is needed in order for all Member State democracies to meet their obligations to their own publics.

Aleksandra Maatsch analyses the conditions under which national parliamentary parties are likely to voice their consent or contestation towards EU policy guidance issued within the framework of the European Semester. The effectiveness of the European Semester has been recognised so far as quite low: EU Member States on average comply with less than $20 \%$ of EU policy guidance and the tendency is decreasing. Maatsch challenges the common opinion attributing low effectiveness of the European Semester to weak knowledge or weak identification with the mechanisms' principles among political parties as well as the weak formal powers of national parliaments in budgetary matters. Analysing two cycles of the European Semester (2014 and 2015) in Austria, Germany, France and Ireland, Maatsch demonstrates that strong formal powers in budgetary matters in 
fact help parties to contest EU policy guidance. Parliaments with strong formal powers in budgetary matters are more likely than weak parliaments to do so. However, according to Maatsch, consent to EU policy guidance depends most on whether it is congruent with the economic interests of political parties (and constituents). The findings demonstrate that the European Semester became an integral part of the national budgetary process structured by the conflict over redistribution. Finally, the article also demonstrates that parliamentary parties acknowledge negative externalities of their national policies if that action does not stand in conflict to their partisan interests.

Ian Cooper's article is more prospective than the others in that it analyses the democratic legitimacy of a new parliamentary body that has been proposed but does not yet exist-a Eurozone parliament. He argues that it is not self-evident which states ought to be represented within such a body, because it is difficult to justify either the exclusion of all non-Eurozone states, or the inclusion of some but not all non-Eurozone states. The question is interlinked with related questions of how the new parliamentary body would be constituted and what powers it would have. Cooper illustrates this difficulty by showing how only certain elements of the post-crisis EU economic governance regime are solely applicable to the Eurozone, and that most elements involve non-Eurozone states to varying degrees. The one new post-crisis parliamentary body, the SECG Conference, when forced to decide which states to include and exclude, decided on broadly inclusive rules of participation. This 'quandary of exclusion' will continue to affect the democratic legitimacy of any future Eurozone parliament even after the UK leaves the EU.

There is considerable variation in the empirical scope of the four research articles presented here. However, a common substantive thread links them, in that they all in different ways address the legitimacy of the European Semester. Christopher Lord offers a comprehensive assessment of its input legitimacy, by examining in detail the various ways in which parliaments at all levels can and should participate in the process. Ian Cooper gives a thorough analysis of one particular aspect of its input legitimacy, regarding which Member States should participate in a new body tasked with the legislative oversight of the European Semester. Adam Cygan offers a critical assessment of the 'throughput' legitimacy (Schmidt, 2006) of certain elements of the European Semester, such as the governance instruments employed (e.g. the Open Method of Coordination) and the balance of substantive policy concerns (fiscal discipline vs. social concerns). And Aleksandra Maatsch gives a thorough analysis of the output legitimacy, i.e. effectiveness, of the European Semester, by showing how EU policy guidance recommendations are received in national parliaments, in particular whether they are an object of consent or contestation within domestic party political systems. 


\section{Conflict of interest}

No conflict of interests to disclose

\section{References}

Cooper, I. (2016) 'The Politicization of Interparliamentary Relations in the EU: Constructing and Contesting the 'Article 13 Conference' on Economic Governance', Comparative European Politics, 14, 196-214.

Crouch, C. (2011) The Strange Non-death of Neoliberalism, Cambridge, Polity Press.

Fasone, C. (2014) 'European Economic Governance and Parliamentary Representation. What Place for the European Parliament?', European Law Journal, 20, 164-185.

Maatsch, A. (2016) 'Drivers of Political Parties' Voting Behaviour in European Economic Governance: The Ultimate Decline of the Economic Cleavage?', West European Politics, 39, 648-666.

Maatsch, A. (2017) Parliaments and the Economic Governance of the European Union: Talking Shops or Deliberative Bodies?, London, Routledge.

Mair, P. (2011) 'Bini Smaghi vs. The Parties: Representative Government and Institutional Constraints', EUI Working Papers, RSCAS 2011/22, European University Institute, Florence.

Merkel, W. (2014) 'Is Capitalism Compatible with Democracy?', Zeitschrift für Vergleichende Politikwissenschaft, 8, 109-128.

Rittberger, B. and Winzen, T. (2015) 'Parlamentarismus nach der Krise: Die Vertiefung Parlamentarischer Asymmetrie in der Reformierten Wirtschafts- und Währungsunion', Politische Vierteljahresschrift, 56, 430-456.

Rose, R. (2014) 'Responsible Party Government in a World of Interdependence', West European Politics, 37, 253-269.

Ruiz Almendral, V. (2015) 'A Myopic Economic Constitution? Controlling the Debt and the Deficit without Fiscal Integration', EUI Law Working Paper no. 2015/12, European University Institute, Florence.

Scharpf, F. W. (2012) 'Legitimacy Intermediation in the Multilevel European Polity and its Collapse in the Euro Crisis', MPifG discussion paper 12-6, Max Planck Institute for the Study of Societies, Cologne.

Schmidt, V. A. (2006) Democracy in Europe: The EU and National Polities, Oxford, Oxford University Press.

Streeck, W. (2014) Buying Time: the Delayed Crisis of Democratic Capitalism, London, Verso.

Thygesen, N. (2013) 'Governance in the Euro Area: Approaching an Optimum Currency Area?' In Verdun, A. and Tovias, A. (eds) Mapping Economic Integration, London, Palgrave Macmillan, pp. 125-146. 